\title{
Improving the Nutritional Values of Cassava Pulp Through Supplementation of Selected Leaves Meal and Fermentation with Chrysonilia Crassa
}

\author{
Sugiharto*, Endang Widiastuti, Turrini Yudiarti, Hanny Indrat Wahyuni and Tri Agus Sartono \\ Department of Animal Science, Faculty of Animal and Agricultural Sciences, Diponegoro University, Semarang, Central \\ Java, Indonesia \\ *Corresponding author email: sgh_undip@yahoo.co.id
}

\begin{abstract}
This study evaluated the impact of fermentation with Chrysonilia crassa on nutritional composition and antioxidative activity of the mixture of cassava pulp and selected leaves meal. Cassava pulp $(60 \mathrm{~g})$ was mixed thoroughly with $35 \mathrm{~g}$ leaves meal of either cassava, M. Oleifera, or L. leucocephala, and inoculated with Chrysonilia crassa starter $(5 \mathrm{~g})$. The mixture was aerobically incubated for 3 days at room temperature and analyzed for the proximate composition, gross energy, true protein, antioxidant activity, and amino acid content. The fermented products showed higher crude protein, ether extract, ash, and gross energy but lower fibre content than unfermented cassava pulp. Both leaves meal supplementation and fermentation increased the true protein content of cassava pulp. Superior antioxidant activities and higher amino acids were observed in the fermented products than raw cassava pulp. In conclusion, supplementation of leaves meal in conjunction with Chrysonilia crassa-fermentation improved the nutritional values and antioxidant potential of cassava pulp.
\end{abstract}

Keywords: cassava pulp, feed, fungal fermentation, leaf meal, nutritional value

\begin{abstract}
Abstrak. Studi ini dilakukan untuk mengevaluasi pengaruh fermentasi menggunakan kapang Chrysonilia crassa terhadap komposisi nutrisi dan aktivitas antioksidan dari campuran onggok dan beberapa tepung daun. Onggok (60 g) dicampur secara merata dengan $35 \mathrm{~g}$ tepung daun singkong, kelor atau lamtoro, dan kemudian diinokulasi memggunakan starter kapang Chrysonilia crassa (5 g). Campuran diinkubasi secara aerobik selama 3 hari pada suhu kamar. Komposisi proksimat, gross energy, true protein, aktivitas antioksidan dan kandungan asam amino selanjutnya ditentukan. Kandungan protein kasar, lemak kasar dan abu lebih besar, sedangkan serat kasar lebih rendah dalam produk yang difermentasi daripada di onggok yang tidak difermentasi. Gross energy lebih tinggi dalam produk yang difermentasi daripada dalam onggok. Suplementasi tepung daun dan fermentasi keduanya meningkatkan kandungan true protein dari onggok. Aktivitas antioksidan dan kandungan asam amino lebih tinggi dalam produk yang difermentasi daripada dalam onggok yang tidak difermentasi. Kesimpulannya, suplementasi tepung daun dan fermentasi menggunakan Chrysonilia crassa meningkatkan nilai nutrisi dan potensi antioksidan dari onggok.
\end{abstract}

Kata kunci: fermentasi, nilai nutrisi, onggok, pakan, tepung daun

\section{Introduction}

Recently, the price of broiler feed increases with the demand for feed ingredients to produce biofuel. Among feed ingredients, energy-rich feedstuffs, such as maize, constitutes the greatest proportion of broiler diets. Today, maize is one of the primary organic stuffs to produce biofuel (Drabik et al., 2016), and hence, a high level of maize incorporated in broiler rations can increase broiler production cost. Accordingly, cheap energy-rich alternative feedstuff for broiler rations is vital for a sustainable chicken production. Many alternative feedstuffs to reduce the proportion of maize in broiler rations include cassava (Manihot esculenta Crantz) pulp. This tapioca by-product is rich in energy and abundant in some tropical countries (Sugiharto et al., 2018a; Sugiharto et al., 2019). In his former study, Khempaka et al (2009) noticed that cassava pulp could partially replace maize in broiler ration. However, cassava pulp should be moderately incorporated due to the high fibre and low protein contents. Alongside fermentation, urea supplementation is common to increase the crude protein content in cassava 
pulp (Khempaka et al., 2014; Sugiharto et al., 2016; Rakhmani and Purwadaria, 2017). Such treatment should, however, be conducted with caution as dietary urea may cause detrimental impacts on the chicken's liver and kidney (Shahzad et al., 2012). The latter organ may suffer particularly due to the incomplete bioconversion of urea (non-protein nitrogen) into protein (microbial protein) during fermentation (Khempaka et al., 2014). Therefore, it is essential to formulate alternatives to urea supplement to enhance the protein level in cassava pulp.

Green foliage has long been included in broiler diets to partially replace the conventional protein-rich feedstuffs (Oluwafemi and Omaku, 2017). Cassava leaf has particularly attracted poultry nutritionists due to its high content of protein, i.e., $28.7 \mathrm{~g} / \mathrm{kg}$ dry matter [DM] (Wyllie and Chamanga 1979). In the studies by Wyllie and Chamanga (1979); Adeyemi et al., (2012); Oluwafemi and Omaku (2017), cassava leaf meal could reduce the use of conventional protein sources, such as soybean meal, fish meal and groundnut cake, in broiler rations. However, the high fibre content and the presence of cyanoglucoside may restrict the proportion of cassava leaf meal in poultry diets (Wyllie and Chamanga, 1979). Moringa oleifera leaf is another foliage with a considerable amount of protein (28.2\% DM) that has substituted conventional protein feed for broiler diets (Tesfaye et al., 2013). However, the protein in $M$. oleifera is less water soluble and has low in vitro digestibility (Teixeira et al., 2014). The latter characteristics may limit the inclusion of $M$. oleifera in broiler rations. The other alternative is Leucaena leucocephala (Hussain et al., 1991) that contains 24.9-34.4\% DM crude protein (Meulen et al., 1979; Ayssiwede et al., 2010) and, the potentially toxic alkaloid mimosine to animals (Meulen et al., 1979, Syamsi et al., 2017).

Fungal solid state fermentation is a standard practice to enhance the nutritional characteristics of feedstuffs (Sugiharto and Ranjitkar, 2019). The fibrolytic activity of the fungus may decrease crude fibre content (Sukma et al 2018), while the increased protein level in fermented product can produce extracellular protein (Liang et al 2009; Sugiharto et al., 2018b).

In this current work, we initially supplemented energy-rich cassava pulp with the selected leaves meal as a protein source prior to fermentation with Chrysonilia crassa fungus. Our previous study showed the potentials of Chrysonilia crassa in lowering the fibre and increasing protein levels of cassava pulp (Sugiharto et al., 2018b). Taken together, Chrysonilia crassa-fermented mixture of cassava pulp and selected leaves meal can decrease fibre and increase protein content in cassava pulp without urea supplementation.

\section{Materials and Methods}

\section{Preparation of Fungal Inoculum}

Chrysonilia crassa fungus was firstly rejuvenated from the stock of fungal culture (potato dextrose agar [PDA] at $4^{\circ} \mathrm{C}$ ). After aerobic incubation at $38^{\circ} \mathrm{C}$ for 2 days, the pure culture was re-grown on chloramphenicolsupplemented PDA for 2 days at $38^{\circ} \mathrm{C}$. The spores of Chrysonilia crassa were dislodged from the PDA culture (in a petri dish, 100×15 $\mathrm{mm}$ ) with $10 \mathrm{~mL}$ sterilized distilled water. The suspension was subsequently used to produce the Chrysonilia crassa starter.

About $100 \mathrm{~g}$ stale rice was soaked in water for about $1 \mathrm{~h}$, steamed for $1 \mathrm{~h}$, and let cool on a tray. Ten $\mathrm{mL}$ of the Chrysonilia crassa suspension was thoroughly mixed with the steamed stale rice and aerobically incubated for 2 days at room temperature. The Chrysonilia crassa-fermented stale rice was sun dried, pulverized, and sieved ( $1 \mathrm{~mm}$ sieve). The starter obtained was used to inoculate the mixture of cassava pulp and the selected leaves meal. 


\section{Preparation of Fermented Mixture of Cassava} Pulp and Selected Leaves Meal

The dried cassava pulp was obtained from local suppliers in Pati, Central Java Province, Indonesia. It was steamed for $1 \mathrm{~h}$ prior to mixing with the selected leaves meal. The leaves of cassava, $M$. oleifera and $L$. leucocephala were collected from the gardens surrounding the campus. The leaves were air dried at room temperature and pulverized (fine powder).

The dried cassava pulp (60 g) was mixed thoroughly with $35 \mathrm{~g}$ of either cassava, $M$. oleifera or L. leucocephala leaves meal. Each mixture was inoculated with Chrysonilia crassa starter (5 g) and added with $100 \mathrm{~mL}$ of sterilized distilled water to obtain $40 \%$ moisture content. The inoculated mixture of cassava pulp and selected leaves meal was aerobically incubated at room temperature for 3 days, sun dried, and stored at room temperature before analysis. The study was conducted in triplicate.

\section{Measurement of Parameters and Statistical Analysis}

The proximate compositions of cassava pulp, leaves meal and fermented mixture of cassava pulp and leaves meal were determined according to the standard proximate analysis (AOAC, 1995). The gross energy of each sample was determined using oxygen bomb calorimeter (Parr Instruments Co., Moline, IL, USA) and benzoic acid was used as a calibration standard. The levels of true protein in each product was determined based on the Lowry method. The antioxidant activities of each stuff were assessed with the 2, 2diphenylpicrylhydrazyl (DPPH) test as described by Wu et al. (2009). The concentration of amino acids in each stuff was determined on the basis of a standard ultra-performance liquid chromatography method (Szkudzińska et al., 2017).

Data collected in the present study were subjected to analysis of variance (SAS Inst. Inc.,
Cary, NC, USA). Any significant effect $(P<0.05)$ across mean values was compared by Duncan's multiple-range test.

\section{Results and Discussion}

Data on the proximate composition of cassava pulp, leaves meal and fermented mixture of cassava pulp and leaves meal are presented in Table 1. The fermented products contained higher crude protein, ether extract (crude fat) and ash $(P<0.001)$ and lower fibre $(P<0.001)$ than the non-fermented cassava pulp. The increased concentrations of crude protein, ether extract, and ash in fermented cassava pulp and leaves meal appeared to contribute to these high proportions. Consecutively, Chrysonilia crassa-fermentation may have increased the abovementioned proximate compositions in the fermented products. Sugiharto et al. (2018a) documented the increased crude protein, ether extract, and ash in some agro-industrial waste (e.g., banana peel, rice bran and cassava pulp) following the fermentation using Chrysonilia crassa.

The fungus' ability to produce extracellular protein and the conversion of starch and nonstarch polysaccharides into monosaccharides (easily converted into fungal protein during fermentation) may account for the increased content of crude protein in the fermented products (Liang et al., 2009; Bayitse et al., 2015). In terms of ether extract, Sukma et al. (2018) suggested that the increased ether extract content may be attributable to the increased fungal biomass during fermentation. It has been known that the plasma membrane and cell wall of fungi are usually composed of ether extract including phospholipid and lipoprotein.

Furthermore, the increased fungal population during fermentation may contribute to the increased ash concentration in the fermented products, since the cell wall of fungus is rich in minerals (Kanghae et al., 2014). 
Table 1. Proximate composition of cassava pulp, leaves meal and fermented mixture of cassava pulp and leaves meal (\% DM)

\begin{tabular}{lccccccccc}
\hline \multicolumn{1}{c}{ Items } & CP & MOLM & CLM & LLLM & FCPMOLM & FCPCLM & FCPLLLM & SEM & P value \\
\hline Crude protein & $2.23^{\mathrm{g}}$ & $29.9^{\mathrm{b}}$ & $30.5^{\mathrm{a}}$ & $29.1^{\mathrm{c}}$ & $17.6^{\mathrm{f}}$ & $19.6^{\mathrm{e}}$ & $19.8^{\mathrm{d}}$ & 0.07 & $<0.001$ \\
Ether extract & $0.66^{\mathrm{e}}$ & $5.44^{\mathrm{a}}$ & $4.74^{\mathrm{b}}$ & $4.80^{\mathrm{b}}$ & $4.23^{\mathrm{c}}$ & $1.63^{\mathrm{d}}$ & $1.82^{\mathrm{d}}$ & 0.14 & $<0.001$ \\
Crude fibre & $32.1^{\mathrm{a}}$ & $11.6^{\mathrm{e}}$ & $26.2^{\mathrm{b}}$ & $21.3^{\mathrm{c}}$ & $9.78^{\mathrm{e}}$ & $19.1^{\mathrm{d}}$ & $18.6^{\mathrm{d}}$ & 0.59 & $<0.001$ \\
Ash & $3.68^{\mathrm{e}}$ & $12.5^{\mathrm{a}}$ & $10.0^{\mathrm{b}}$ & $9.69^{\mathrm{c}}$ & $10.1^{\mathrm{b}}$ & $8.82^{\mathrm{d}}$ & $8.91^{\mathrm{d}}$ & 0.06 & $<0.001$ \\
\hline
\end{tabular}

a-gValues with various letters within the same row are substantially distinct; DM: dry matter, CP: cassava pulp, MOLM: $M$. oleifera leaf meal, CLM: cassava leaf meal, LLLM: L. leucocephala leaf meal, FCPMOLM: fermented mixture of cassava pulp and $M$. oleifera leaf meal, FCPCLM: fermented mixture of cassava pulp and cassava leaf meal, FCPLLLM: fermented mixture of cassava pulp and $L$. leucocephala leaf meal, SEM: standard error of the mean

Table 2. Gross energy, true protein and antioxidant activity of cassava pulp, leaves meal and fermented mixture of cassava pulp and leaves meal

\begin{tabular}{|c|c|c|c|c|c|c|c|c|c|}
\hline Items & CP & MOLM & CLM & LLLM & FCPMOLM & FCPCLM & FCPLLLM & SEM & $P$ value \\
\hline $\begin{array}{l}\text { Gross energy } \\
\text { (kcal/kg DM) }\end{array}$ & $3842^{d}$ & $4320^{b}$ & $4255^{c}$ & $4352^{b}$ & $4365^{b}$ & $4436^{a}$ & $4334^{b}$ & 18.1 & $<0.001$ \\
\hline $\begin{array}{l}\text { True protein } \\
\text { (\% DM) }\end{array}$ & $0.40^{\mathrm{g}}$ & $24.7^{\mathrm{a}}$ & $2.46^{f}$ & $13.0^{\mathrm{b}}$ & $7.62^{d}$ & $8.92^{c}$ & $5.64^{\mathrm{e}}$ & 0.09 & $<0.001$ \\
\hline $\begin{array}{l}\text { Antioxidant } \\
\text { activity }\left(I C_{50} * \text {, }\right. \\
\text { ppm) }\end{array}$ & $2975^{a}$ & $330^{f}$ & $165^{\mathrm{g}}$ & $1092^{c}$ & $941^{d}$ & $2456^{b}$ & $570^{e}$ & 22.5 & $<0.001$ \\
\hline
\end{tabular}

a-gValues with various letters within the same row are substantially distinct; ${ }^{*}$ IC50 is recognized as the potent concentration at which the 2,2-diphenylpicrylhydrazyl (DPPH) radicals were neutralized by about 50\%. A higher of DPPH radical scavenging activity can be attributed to a lower IC50 value; DM: dry matter, CP: cassava pulp, MOLM: M. oleifera leaf meal, CLM: cassava leaf meal, LLLM: L. leucocephala leaf meal, FCPMOLM: fermented mixture of cassava pulp and $M$. oleifera leaf meal, FCPCLM: fermented mixture of cassava pulp and cassava leaf meal, FCPLLLM: fermented mixture of cassava pulp and L. leucocephala leaf meal, SEM: standard error of the mean.

It was apparent in the current work that the fibre concentration was lower $(P<0.001)$ in the fermented products than the raw cassava pulp. The lower content of fibre in the leaves meal supplemented into cassava pulp may be associated with the reduced fibre content in the mixture of cassava pulp and leaves meal. In addition, the fungal fermentation was most likely to help decrease the fibre content in the mixture of cassava pulp and leaves meal. Fungus have rhizoids to penetrate substrates and is able to produce the essential fibredegrading enzymes to break down the complex fibre, thus decreasing the fibre content of the fermented products (Sukma et al., 2018).

Data on the gross energy, true protein, and antioxidant activity of cassava pulp, leaves meal, and fermented mixture of cassava pulp and leaves meal are presented in Table 2. It was evident that gross energy was greater $(P<0.001)$ in the fermented products than in nonfermented cassava pulp. The contribution of leaves meal in elevating the gross energy of cassava pulp was undoubtful because compared to raw cassava pulp, leaves meal had a higher gross energy.

Fermentation also appeared to play a significant role in increasing the gross energy of cassava pulp. Fathy et al., (2018) reported that fermentation with Kluyveromyces marxianus fungus increased the gross energy of olive pomace. The mechanisms through which fungal fermentation increased the gross energy content of fermented products was not definitely known, but the increased contents of crude protein and ether extract and the reduced content of fibre may be due to the increased gross energy in the fermented products.

Interestingly, we found that both leaves meal supplementation and fungal fermentation were capable of elevating $(P<0.001)$ the true protein concentration of cassava pulp. Fathy et al. (2018) documented that fungal fermentation 
enhanced the concentration of digestible crude protein in olive pomace. Similarly, an increased true protein concentration was reported in cassava peel after fermentation with Trichoderma viride (Ezekiel et al.,2010), and in cocoa pod husk after fermentation with Aspergillus oryzae (Rakhmani and Purwadaria, 2017) .

The antioxidant activities were higher $(P<0.001)$ in the fermented products when compared with that in the raw cassava pulp. Besides the rich phenolic compounds in leaves meal (Sugiharto et al., 2019), the fungal fermentation effect helps augment the antioxidant activities of the fermented products. Sugiharto et al. (2018) previously documented that fermentation with Chrysonilia crassa can enhance the antioxidant capacity of rice bran. Bier et al. (2019) noted that fungal fermentation using Diaporthe sp. enhanced the antioxidant activity of orange waste.

The production of phenolic components containing high antioxidant potentials during fermentation process (Bier et al., 2019) as well as the increased quantity of fungal biomass (Sugiharto et al., 2016) were responsible for the elevated antioxidant potentials of the fermented products. Sugiharto et al. (2017) pointed out that the fungus Chrysonilia crassa exhibited antioxidant potentials corresponding to ascorbic acid that is a standard antioxidant in DPPH assays (Sugiharto et al., 2016).

Data on amino acid contents of cassava pulp, leaves meal, and fermented mixture of cassava pulp and leaves meal are listed in Table 3. In general, the content of amino acids was greater $(P<0.001)$ in the fermented products than in raw cassava pulp. The contribution of amino acids from the leaves meal may have enhanced the concentration of amino acids in the fermented products. Similar to crude protein, fungal fermentation was most likely to increase amino acid concentration in the fermented products. Indeed, Sugiharto et al. (2018) previously documented that fermentations with Chrysonilia crassa can increase amino acid level in banana peel meal.

Table 3. Amino acid contents of cassava pulp, leaves meal and fermented mixture of cassava pulp and leaves meal $(\mathrm{mg} / \mathrm{kg})$

\begin{tabular}{|c|c|c|c|c|c|c|c|c|c|}
\hline Items & $\mathrm{CP}$ & MOLM & CLM & LLLM & $\begin{array}{c}\text { FCPMO } \\
\text { LM }\end{array}$ & $\begin{array}{c}\text { FCPCL } \\
M\end{array}$ & $\begin{array}{c}\text { FCPLLL } \\
M\end{array}$ & SEM & $P$ value \\
\hline Glycine & $1.08^{\mathrm{e}}$ & $12.5^{\mathrm{a}}$ & $11.1^{\mathrm{b}}$ & $11.1^{\mathrm{b}}$ & $7.29^{\mathrm{cd}}$ & $7.42^{c}$ & $6.72^{d}$ & 0.22 & $<0.001$ \\
\hline L-Alanine & $1.29^{f}$ & $13.2^{\mathrm{a}}$ & $12.3^{b}$ & $9.82^{c}$ & $7.20^{d}$ & $6.99^{d}$ & $6.60^{\mathrm{e}}$ & 0.96 & $<0.001$ \\
\hline L-Arginine & $0.89^{f}$ & $11.4^{c}$ & $13.8^{\mathrm{a}}$ & $12.9^{\mathrm{b}}$ & $6.85^{d}$ & $6.35^{d}$ & $5.39^{e}$ & 0.28 & $<0.001$ \\
\hline L-Aspartate acid & $1.65^{f}$ & $22.6^{c}$ & $50.2^{a}$ & $34.0^{\mathrm{b}}$ & $11.3^{d}$ & $9.81^{\mathrm{e}}$ & $10.1^{\mathrm{e}}$ & 0.25 & $<0.001$ \\
\hline L-glutamic acids & $1.91^{\mathrm{e}}$ & $31.6^{a}$ & $31.1^{\mathrm{a}}$ & $19.8^{\mathrm{b}}$ & $14.7^{c}$ & $13.4^{d}$ & $12.8^{d}$ & 0.24 & $<0.001$ \\
\hline L-Phenylalanine & $0.91^{e}$ & $12.8^{\mathrm{b}}$ & $14.0^{\mathrm{a}}$ & $12.4^{\mathrm{b}}$ & $6.70^{c}$ & $6.38^{c}$ & $5.47^{d}$ & 0.25 & $<0.001$ \\
\hline L-Histidine & $0.46^{\mathrm{e}}$ & $5.45^{\mathrm{a}}$ & $5.72^{a}$ & $4.80^{\mathrm{b}}$ & $2.90^{c}$ & $2.78^{\mathrm{cd}}$ & $2.50^{d}$ & 0.11 & $<0.001$ \\
\hline L-Isoleucine & $0.73^{e}$ & $9.27^{\mathrm{b}}$ & $9.68^{a}$ & $8.96^{\mathrm{b}}$ & $6.08^{c}$ & $5.94^{c}$ & $5.34^{d}$ & 0.11 & $<0.001$ \\
\hline L-Leucine & $1.32^{f}$ & $17.5^{\mathrm{a}}$ & $17.5^{\mathrm{a}}$ & $16.4^{\mathrm{b}}$ & $11.2^{c}$ & $10.3^{d}$ & $9.33^{\mathrm{e}}$ & 0.26 & $<0.001$ \\
\hline L-Lysine $\mathrm{HCL}$ & $1.33^{f}$ & $11.4^{\mathrm{b}}$ & $13.3^{\mathrm{a}}$ & $10.8^{c}$ & $7.16^{d}$ & $6.63^{\mathrm{e}}$ & $6.92^{d}$ & 0.84 & $<0.001$ \\
\hline L-Proline & $1.13^{d}$ & $10.5^{a}$ & $10.1^{\mathrm{ab}}$ & $9.82^{\mathrm{b}}$ & $5.91^{c}$ & $5.75^{c}$ & $5.66^{c}$ & 0.11 & $<0.001$ \\
\hline L-Serine & $1.35^{d}$ & $11.5^{\mathrm{b}}$ & $13.9^{a}$ & $11.0^{\mathrm{b}}$ & $7.19^{c}$ & $6.98^{c}$ & $6.71^{c}$ & 0.24 & $<0.001$ \\
\hline L-Threonine & $1.13^{f}$ & $9.62^{b}$ & $8.87^{c}$ & $10.6^{a}$ & $6.67^{d}$ & $6.43^{d}$ & $5.72^{\mathrm{e}}$ & 0.22 & $<0.001$ \\
\hline L-Tyrosine & $0.31^{\mathrm{e}}$ & $5.55^{\mathrm{b}}$ & $6.47^{a}$ & $6.51^{\mathrm{a}}$ & $3.75^{c}$ & $3.33^{\mathrm{cd}}$ & $3.04^{d}$ & 0.21 & $<0.001$ \\
\hline L-Valine & $1.11^{\mathrm{e}}$ & $12.2^{\mathrm{a}}$ & $12.0^{\mathrm{a}}$ & $11.4^{\mathrm{b}}$ & $7.48^{c}$ & $7.07^{\mathrm{cd}}$ & $6.61^{d}$ & 0.18 & $<0.001$ \\
\hline
\end{tabular}

a-fValues with various letters within the same row are substantially distinct; CP: cassava pulp, MOLM: $M$. oleifera leaf meal, CLM: cassava leaf meal, LLLM: L. leucocephala leaf meal, FCPMOLM: fermented mixture of cassava pulp and M. oleifera leaf meal, FCPCLM: fermented mixture of cassava pulp and cassava leaf meal, FCPLLLM: fermented mixture of cassava pulp and $L$. leucocephala leaf meal, SEM: standard error of the mean 
Bujang et al. (2014) suggested that the conversion of protein into amino acids by protease enzyme produced by the filamentous fungi may result in elevated free amino acids in the fermented stuffs. Considering that the biomass of fungi contains high concentration of amino acids (Karimi et al., 2018), the increased quantity of fermented fungal biomass can enhance the level of amino acid the fermented products.

\section{Conclusions}

Supplementation of leaves meal in
conjunction with Chrysonilia crassafermentation improved the nutritional values and antioxidant potentials of cassava pulp. This method may be applied to produce the cheap alternative feedstuffs for maize.

\section{References}

Adeyemi, OA, JA Adekoya, and RA Sobayo. 2012. Performance of broiler chickens fed diets containing cassava leaf: blood meal mix as replacement for soybean meal. Revista Científica UDO Agrícola. 12(1): 212-219.

AOAC. 1995. Official methods of analysis of the association of analytical chemists. Washington DC, USA.

Ayssiwede, SB, A Dieng, C Chrysostome, W Ossebi, JL Hornick, and A Missohou. 2010. Digestibility and metabolic utilization and nutritional value of Leucaena leucocephala (Lam.) leaves meal incorporated in the diet of indigenous Senegal chickens. International Journal of Poultry Science. 9(8): 767-776.

Bayitse, R, X Hou, G Laryea, and A B Bjerre. 2015. Protein enrichment of cassava residue using Trichoderma pseudokoningii (ATCC 26801). AMB Express. 5(1): 80.

Bier, MC, ABP Medeiros, N De Kimpe, and CR Soccol. 2019. Evaluation of antioxidant activity of the fermented product from the biotransformation of R-(+)-limonene in solid-state fermentation of orange waste by Diaporthe sp. Biotechnology Research and Innovation. 3(1): 168-176.

Bujang, A, and NA Taib. 2014. Changes on amino acids content in soybean, garbanzo bean and groundnut during pre-treatments and tempe making. Sains Malaysiana. 43(4): 551-557.

Drabik, D, P Ciaian, and J Pokrivčák. 2016. The effect of ethanol policies on the vertical price transmission in corn and food markets. Energy Economics. 55(2016): 189-199.

Ezekiel, OO, OC Aworh, HP Blaschek and TC Ezeji. 2010. Protein enrichment of cassava peel by submerged fermentation with Trichoderma viride (ATCC 36316). African Journal of Biotechnology. 9(2): 187-194.

Fathy, SA, AE Mahmoud, MM Rashad, MK Ezz, and AT Mohammed. 2018. Improving the nutritive value of olive pomace by solid state fermentation of Kluyveromyces marxianus with simultaneous production of gallic acid. International Journal of Recycling of Organic Waste in Agriculture. 7: 135141.

Hussain, J, PVVS Reddy, and VR Reddy. 1991. Utilisation of leucaena leaf meal by broilers. British Poultry Science. 32(1): 131-137.

Kanghae, A, PD Eungwanichayapant, P Chueamchaitrakun, S Nitsawang, and $E$ Chukeatirote. 2014. Proximate analysis of the fermented soybean prepared by Bacillus subtilis and Rhizopus oligosporus. The 26th Annual meeting of the Thai Society for Biotechnology and International Conference, Mae Fah Lunag University, Chiang Rai, 26-29 Nov, 2014.

Karimi, S, NM Soofiani, A Mahboubi, and MJ Taherzadeh. 2018. Use of organic wastes and industrial by-products to produce filamentous fungi with potential as aqua-feed ingredients. Sustainability. 10(9): 3296.

Khempaka, S, W Molee and M Guillaume. 2009. Dried cassava pulp as an alternative feedstuff for broilers: Effect on growth performance, carcass traits, digestive organs, and nutrient digestibility. The Journal of Applied Poultry Research. 18(3): 487-493.

Khempaka, S, R Thongkratok, S Okrathok, and W Molee. 2014. An evaluation of cassava pulp feedstuff fermented with $A$. oryzae, on growth performance, nutrient digestibility and carcass quality of broilers. Journal of Poultry Science, 51(1): 71-79.

Liang, Y, L Pan and Y Lin. 2009. Analysis of extracellular proteins of Aspergillus oryzae grown on soy sauce koji. Bioscience, Biotechnology, and Biochemistry. 73(1): 192-195.

Meulen, U, S Struck, E Schulke and EAEI Harith. 1979. $A$ review on the nutritive value and toxic aspects of Leucaena leucocephala. Tropical Animal Production. 4: 113-126.

Oluwafemi, RA, and G Omaku. 2017. Nutritional evaluation of cassava leaf meal based diets on broiler starter chicks performance. International Journal of Food Science and Nutrition. 2: 42-45.

Rakhmani, SIW, and T Purwadaria. 2017. Improvement of nutritional value of cocoa pod husk fermented with Aspergillus spp. and two 
levels of urea and ammonium sulphate. Jurnal Ilmu Ternak dan Veteriner. 22(3): 101-113.

Shahzad, MN, MT Javed, S Shabir, M Irfan and R Hussain. 2012. Effects of feeding urea and copper sulphate in different combinations on live body weight, carcass weight, percent weight to body weight of different organs and histopathological tissue changes in broilers. Experimental and Toxicologic Pathology. 64(3): 141-147.

Sugiharto, S, T Yudiarti and I Isroli. 2016. Haematological and biochemical parameters of broilers fed cassava pulp fermented with filamentous fungi isolated from the Indonesian fermented dried cassava. Livestock Research for Rural Development. 28(4).

Sugiharto, S, I Isroli, T Yudiarti, E Widiastuti, H I Wahyuni and T A Sartono. 2018. Effect of twostep fermentation by Chrysonilia crassa and Bacillus subtilis on nutritional values and antioxidative properties of agro-industrial byproducts as poultry feed ingredients. Journal of Advanced Veterinary and Animal Research. 5(4): 472-480.

Sugiharto, S, T Yudiarti, I Isroli and E Widiastuti. 2018. The potential of tropical agro-industrial byproducts as a functional feed for poultry. Iranian Journal of Applied Animal Science. 8(3):375-385.

Sugiharto, S. 2019. A review on fungal fermented cassava pulp as a cheap alternative feedstuff in poultry ration. Journal of World's Poultry Research. 9(1): 1-6.

Sugiharto, S and S Ranjitkar. 2019. Recent advances in fermented feeds towards improved broiler chicken performance, gastrointestinal tract microecology and immune responses: A review. Animal Nutrition. 5(1):1-10.

Sukma, A, B Jos and S Sumardiono. 2018. Kinetic of biomass growth and pro-tein formation on rice bran fermentation using Rhizopus oryzae. MATEC Web of Conferences, 156(01023).

Syamsi, A N, FM Suhartati and W Suryapratama. 2017. Pengaruh Daun Turi (Sesbania grandiflora) dan Lamtoro (Leucaena leucocephala) dalam Ransum Sapi Berbasis Indeks Sinkronisasi Protein - Energi Terhadap Sintesis Protein Mikroba Rumen. Pastura. 6(2):47-52.

Szkudzińska, K, I Smutniak, J Rubaj, W Korol and G Bielecka. 2017. Method validation for determination of amino acids in feed by UPLC. Accreditation and Quality Assurance. 22:247-252.

Teixeira, EMB, MRB Carvalho, VA Neves, MA Silva and L Arantes-Pereira. 2014. Chemical characteristics and fractionation of proteins from Moringa oleifera Lam. Leaves. Food Chemistry. 147:51-54.

Tesfaye, E, G Animut, M Urge, and T Dessie. 2013. Moringa olifera Leaf meal as an alternative protein feed ingredient in broiler ration. International Journal of Poultry Science. 12(5):289-297.

Wu, N, K Fu, YJ Fu, YG Zu, FR Chang, YH Chen, XL Liu, $Y$ Kong, W Liu and CB Gu. 2009. Antioxidant activities of extracts and main components of pigeonpea [Cajanus cajan (L.) Millsp.] leaves. Molecules. 14(3):1032-1043.

Wyllie D, and PJ Chamanga. 1979. Cassava leaf meals in broiler diets. Tropical Animal Production. 4:232-240. 